\title{
Physiological responses of Macoma balthica to copper pollution in the Baltic
}

\author{
Adam SOKOLOWSKI ${ }^{\text {a }}$, Maciej WOLOWICZ ${ }^{\text {a }}$, Herman HUMMEL ${ }^{\text {b }}$, Roelof BOGAARDS ${ }^{\text {b }}$ \\ ${ }^{a}$ University of Gdansk, Institute of Oceanography, Laboratory of Estuarine Ecology, Al. Marszalka Pilsudskiego 46, \\ 81 - 378 Gdynia, Poland \\ ${ }^{b}$ Netherlands Institute of Ecology, Centre for Estuarine and Coastal Ecology, Korringaweg 7, 4401 NT Yerseke, \\ The Netherlands
}

(Received 27 May 1998, revised 16 October 1998, accepted 7 December 1998)

\begin{abstract}
Physiological and behavioral responses to $\mathrm{Cu}$ exposure were measured in the Baltic clam Macoma balthica from the Gulf of Gdansk, southern Baltic Sea. The burrowing activity, mortality rate, glycogen content, condition index and free amino acid (FAA) composition were analysed as indicators of stress in a series of field and laboratory studies. $M$. balthica exposed to $\mathrm{Cu}$ showed clear $\mathrm{Cu}$-concentration related differences in burrowing activity and mortality rate, but no consistent differences in the condition index, glycogen content, and free amino acids. The clams from a less polluted area reacted more strongly and were more sensitive to additional stress as compared to organisms from a more polluted region. The effect of $\mathrm{Cu}$ on the ecophysiology of Baltic clams in the field was probably obscured by reproduction-related changes in the organism. The role of sediment as a potential source of $\mathrm{Cu}$ in the Baltic clam was discussed. (C) Elsevier, Paris / Ifremer / CNRS / IRD
\end{abstract}

\section{stress / copper / ecophysiology / Macoma balthica / Baltic Sea}

Résumé - Réponses physiologiques de Macoma bathica à la pollution par le cuivre en mer Baltique. Des réponses physiologiques et comportementales vis-à-vis d'une exposition au cuivre ont été mesurées chez le bivalve endobenthique, Macoma balthica, du golfe de Gdansk (sud de la mer Baltique). La capacité d'enfouissement, le taux de mortalité, la teneur en glycogène, l'indice de condition et la composition en acides aminés libres ont été analysés, en tant que bio-indicateurs de stress, dans une série d'études de terrain ainsi qu'au laboratoire. Expérimentalement, $M$. balthica exposée au cuivre a montré clairement des différences, liées à la concentration en cuivre, dans la capacité d'enfouissement et le taux de mortalité, mais aucune différence cohérente dans la condition, la teneur en glycogène et en acides aminés libres. Les bivalves issus d'un site moins pollué ont réagi davantage et ont été plus sensibles à un stress supplémentaire, en comparaison à des organismes issus d'une région plus polluée. Sur le terrain, l'effet du cuivre sur l'écophysiologie du bivalve a probablement été masqué par des modifications liées à la reproduction. Le rôle du sédiment est envisagé comme source potentielle de cuivre pour l'espèce étudiée. (C) Elsevier, Paris / Ifremer / CNRS / IRD

stress / cuivre / écophysiologie / Macoma balthica / mer Baltique

\section{INTRODUCTION}

A number of unfavorable changes caused by human activities have been observed in the marine ecosystem of the Gulf of Gdansk, southern Baltic Sea, in recent years. Effects have appeared in a bottom zone where oxygen deficiency, the presence of hydrogen sulphide as well as accumulation of trace metals (e.g. $\mathrm{Cu}, \mathrm{Pb}, \mathrm{Zn}, \mathrm{Cd}$ ) have been recorded. The region affected by $\mathrm{Cu}$ contamination is an estuarine area near the mouth of the Vistula River. In the Polish zone of the southern Baltic Sea more than $80 \%$ of the total efflux of metallic pollutants originates from the Vistula (e.g. $87 \%$ of $\mathrm{Cu}, 98 \%$ of $\mathrm{Zn}$ and $\mathrm{Cd}$, $95 \%$ of $\mathrm{Ni}, 77 \%$ of $\mathrm{Co}$ ) [28]. Since Cu exhibits an affin- 
ity for organic matter and the particulate phase, a significant part of its load precipitates to the sea bed, enriching sediments. According to Szefer et al. [29] and Sokolowski et al. (unpubl. data) the $\mathrm{Cu}$ content in the $<63 \mu \mathrm{m}$ fraction of surface sediments displays a distinct gradient with maximum values at $20 \mathrm{~m}$ water depth and a decrease in offshore and inshore directions. Variable $\mathrm{Cu}$ concentrations in sediments and the continental input of $\mathrm{Cu}$ from the river indicate a concern on $\mathrm{Cu}$ accumulation in bivalves in the Vistula estuary.

The Baltic clam Macoma balthica (L.) is widely distributed in the Baltic Sea where it plays a dominant role within the macrozoobenthos in the Gulf of Gdansk. Since the beginning of the 1980s a rise in biomass of this species has been noted [34]. M. balthica inhabits seriously polluted regions where other benthic species such as Nereis diversicolor and Saduria entomon are absent [16] or reduced [32]. This may indicate a broad range of tolerance and large adaptative potential of the clam, and presumably effective physiological $[31]$ and genetic $[12,30]$ adaptations.

In other areas, the sensitivity of the clam to $\mathrm{Cu}$ is well established $[7,13,14]$. While the majority of previous studies focused on Atlantic specimens, and probably different races or ecotypes of clams living in the Baltic [23, 30], littlc is known about ccophysiological reactions of Baltic populations. Laboratory experiments indicated that lower burrowing rates and an increase in mortality seemed to be the first responses to increased $\mathrm{Cu}$ concentrations [13, 14]. Neuhoff [25] and Lagadic et al. [18] observed that long-term exposure to increased $\mathrm{Cu}$ concentrations, which exceeded the physiological requirements, might affect metabolic activity. Consistently, organisms suffered from a higher energy charge and oxygen consumption and higher use of its energy reserve. Moreover, $\mathrm{Cu}$ is also supposed to bring about a change in the total quantity of free amino acids (FAA) and its composition (e.g. the taurine/glycine ratio and/or the sum of threonine and serine) $[15,19]$. As a result, the biochemical composition and condition index are changed.

In this study, the effect of $\mathrm{Cu}$ on the ecophysiology and behaviour of $M$. balthica was tested under field and experimental conditions. Glycogen content, the condition index and free amino acid composition were employed as indicators of stress. Interpopulation differences in the sensitivity to $\mathrm{Cu}$ for organisms collected from two stations, differing in their degree of pollution, were also investigated. The relation between the $\mathrm{Cu}$ content in soft tissues and the fine-grained fraction of sediments provided information for the assessment of sediments as a potential source of the metal to the bivalve.

\section{MATERIALS AND METHODS}

\subsection{Field studies}

Materials were collected from six stations along the linear profile, from the Vistula River mouth towards an open part of the Gulf of Gdansk, in April and June 1995 (figure 1). Sampling points were selected to represent the expected range of $\mathrm{Cu}$ concentrations in the $<63 \mu \mathrm{m}$ sediment fraction. A polyethylene sediment corer of a $20 \mathrm{~mm}$ diameter was used to sample the upper $50 \mathrm{~mm}$ of sediments. This layer of the substrate was found to be within an optimal burrowing depth of Macoma balthica. M. balthica, $>10 \mathrm{~mm}$ long, live at an average depth of $20 \mathrm{~mm}$ in summer compared to $50 \mathrm{~mm}$ in winter [33]. Organisms were collected with a rectangular grab with a net of $3 \mathrm{~mm}$ mesh. The bivalves (10-67 individuals), ranging in shell length from 15 to $19.9 \mathrm{~mm}$, were depurated for $24 \mathrm{~h}$ in filtered estuarine water at ambient salinity and temperature.

The sediments were preliminarily dried at $50^{\circ} \mathrm{C}$ to a constant weight, sieved through a $63 \mu \mathrm{m}$ nylon mesh [29] and divided into two subsamples. Organic matter content in the $<63 \mu \mathrm{m}$ fraction was computed from the loss in weight of a dry subsample burned at $550^{\circ} \mathrm{C}$ for $6 \mathrm{~h}$. The second subsample was leached with $1 \mathrm{M} \mathrm{HCl}$ according to Luoma and Bryan [20]. This extraction technique allowed determination of the labile and potentially bioavailable $\mathrm{Cu}$ species in the sediments [6]. Five individuals were chosen randomly from each sample and total shell length and dry weight of soft tissue (DW) were recorded in order to calculate the condition index (C.I.). The condition index was expressed as the ratio of dry weight to volume. Volume was estimated by length $\left(\mathrm{L}^{3}\right)$ [3]. Dry soft tissues were pooled, homogenised and digested in concentrated $\mathrm{HNO}_{3}$. $\mathrm{Cu}$ concentrations were measured by atomic absorption spectrophotometry (AAS). Glycogen content was assessed according to Dubois et al. [8]. Multiple and stepwise regression analyses were performed by means of the Systat Statistical Package $(p<0.05)[27]$. 


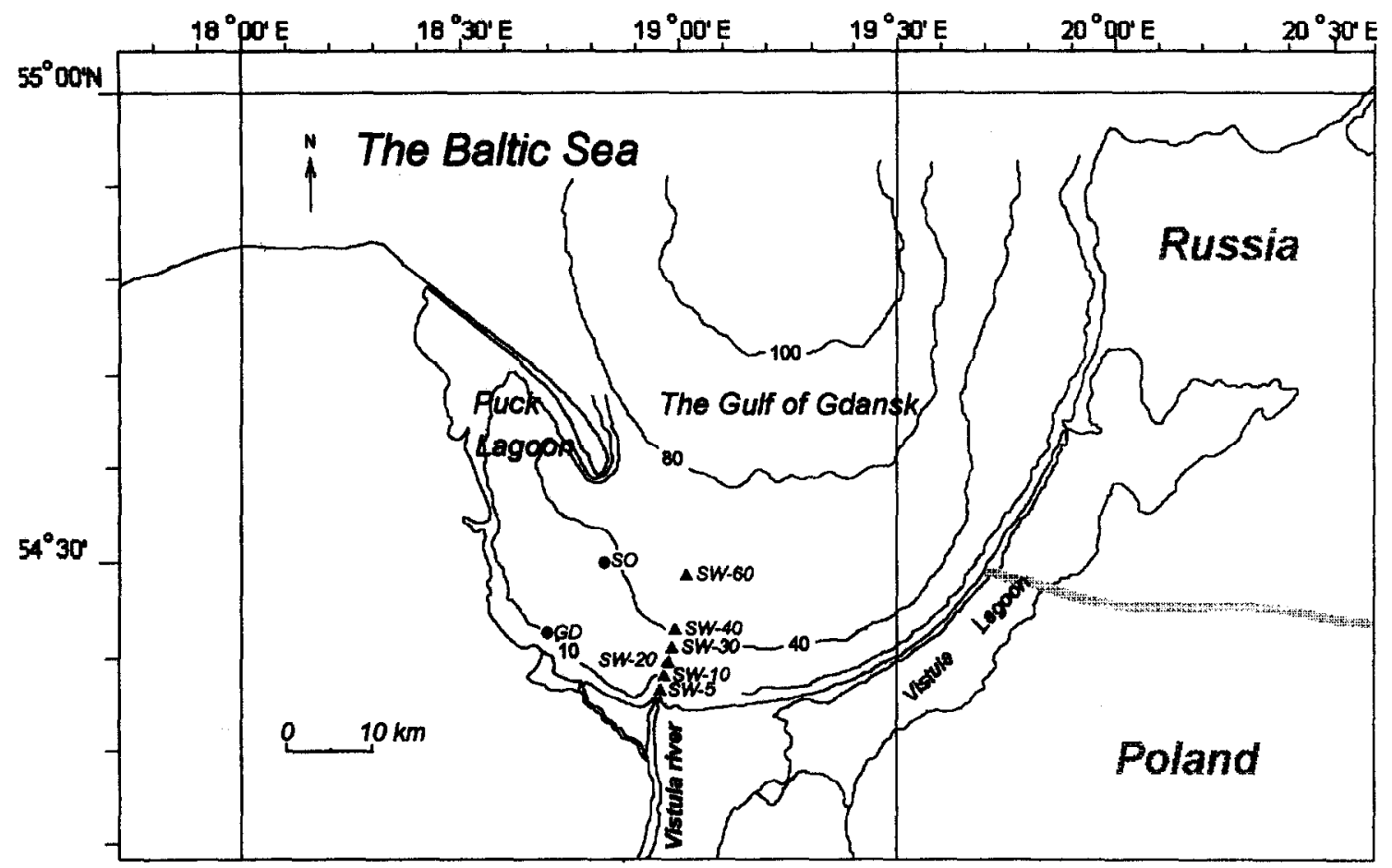

Figure 1. Location of sampling stations.

\subsection{Experimental setup}

Adult Macoma balthica were collected from two stations (figure 1 ) considered to be heavily polluted with trace metals (GD) and relatively unpolluted (SO) in May-June [2]. Station GD was located in the industrial zone, in front of the big trans-shipping port in Gdansk, station SO was located in the open part of the Gulf of Gdansk.
Detailed characteristics of sampling points are shown in table I.

The experiment was conducted for two months in three $30 \mathrm{~L}$ aquaria with different initial dissolved $\mathrm{Cu}$ concentrations: a control (no $\mathrm{Cu}$ added), 37.5 and $75 \mu \mathrm{g} \mathrm{L}^{-1}$ (added from a stock solution of $0.5 \mathrm{M} \mathrm{Cu}\left(\mathrm{NO}_{3}\right)_{2} \cdot 3 \mathrm{H}_{2} \mathrm{O}$ in $\mathrm{HNO}_{3}$ ). Continuous water circulation through aquaria

Table I. Characteristics of sampling stations

\begin{tabular}{|c|c|c|c|c|}
\hline Station & Depth & Salinity & $\begin{array}{l}\text { Distance from } \\
\text { the river mouth } \\
\text { (km] }\end{array}$ & Type of sediment \\
\hline$S W-5$ & 5 & $7.4 \pm 0.2$ & 1.4 & sand \\
\hline$S W-10$ & 10 & $7.5 \pm 0.0$ & 1.6 & sand \\
\hline$S W-20$ & 20 & $7.4 \pm 0.1$ & 2.7 & sand \\
\hline$S W-30$ & 30 & $7.5 \pm 0.1$ & 5.6 & sand \\
\hline$S W-40$ & 40 & $7.5 \pm 0.0$ & 7.4 & mud \\
\hline$S W-60$ & 60 & $7.6 \pm 0.2$ & 9.7 & mud \\
\hline Gdansk (GD) & 10 & $7.0 \pm 0.5$ & * & mud \\
\hline Sopot (SO) & 37 & $7.0 \pm 0.5$ & $*$ & sand \\
\hline
\end{tabular}

* - not in the Vistula River transect. 
was assured using water pumps. Prior to the experiment, organisms were acclimatised for $12 \mathrm{~h}$ to temperature and salinity rendering ambient environmental situation, $12.3 \pm 0.5^{\circ} \mathrm{C}$ and $10 \pm 0.5$, respectively. 100 individuals from each population were divided over four small aquaria (25 individuals per aquarium) to enable replicate analysis $(n=4)$. Animals were fed the algae Phaeodactylum iricornulum every two days, six hours prior to changing the water. For each treatment, water samples for $\mathrm{Cu}$ analysis were taken four times and immediately filtered on cellulose-nitrate filters $(0.45 \mu \mathrm{m})$ to distinguish between dissolved and particulate phases. Dissolved $\mathrm{Cu}$ concentrations were measured by differential pulse anodic stripping voltametry (DPASV), using a hanging drop mercury electrode (HDME) and collection potential $-0.6 \mathrm{~V}$, after UV irradiation with $\mathrm{H}_{2} \mathrm{O}_{2}$ for $4 \mathrm{~h}$ [21]. Particulate $\mathrm{Cu}$ was leached with $1 \mathrm{M} \mathrm{HCl}$ and measured by AAS. The quality of the methods used was controlled by simultaneous $\mathrm{Cu}$ analyses of an internal standard and an external Titrisol calibration solution (Merck) for the dissolved and the particulate $\mathrm{Cu}$, respectively. The detailed description of the procedures and analytical quality data are given in Gerringa et al. [10] and Nieuwenhuize et al. [26]. The mortality was checked every day and the experiment was stopped when mortality reached $50 \%$. The test for burrowing activity was carried out on twenty individuals of each population at the beginning and at the end of the experiment. The clams were introduced into aquaria with $15 \mathrm{~cm}$ of sandy sediment and the amount of totally burrowed animals was counted after 60 and $90 \mathrm{~min}$. In addition, at the end of each exposure, the condition index (C.I.) (on ten individuals) as well as protein [11] and glycogen content (on pooled samples) [17] were determined. The composition of the following free amino acids (FAA) was analysed on a LKB 4151 Alpha Plus amino acid analyser: aspartic acid-Asp, glutamic acid-Glu, serine-
Ser, glycine-Gly, taurine-Tau, arginine-Arg, alanine-Ala, valine-Val, phenylalanine-Phe, isoleucine-lle, and leucine-Leu.

\section{RESULTS}

\subsection{Field studies}

The $\mathrm{Cu}$ content in the $<63 \mu \mathrm{m}$ fraction was maximal at station SW-20, with lower values at both the shallower and the deeper stations (table $I I$ ). The $\mathrm{Cu}$ content was related to the organic fraction $(\mathrm{r}=0.82, \mathrm{n}=10, \mathrm{p}<0.01$; table IV; figure 2). The Cu concentration in Macoma balthica showed an increasing trend towards the deeper sta-

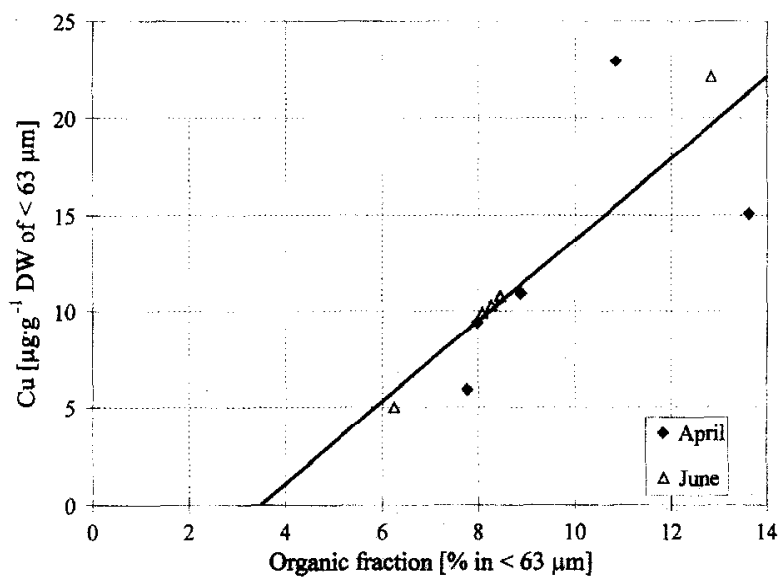

Figure 2. Correlation between $\mathrm{Cu}$ content in silt fraction and organic matter content in silt fraction of surface sediments $(r=$ $0.82, \mathrm{n}=10, \mathrm{p}<0.01$ )

Table II. Cu content, organic matter content and percentage of silt fraction $(<63 \mu \mathrm{m})$ in surface sediments in the Vistula River estuary $($ dash no data).

\begin{tabular}{|c|c|c|c|c|c|c|}
\hline \multirow[t]{2}{*}{ Station } & \multicolumn{2}{|c|}{$\begin{array}{c}\text { Cu content } \\
\text { in }<63 \mu \mathrm{m} \text { fraction } \\
{\left[\mu \mathrm{g} \mathrm{g}^{-1} \mathrm{DW}\right]}\end{array}$} & \multicolumn{2}{|c|}{$\begin{array}{c}\text { Organic matter content } \\
\text { in }<63 \mu \mathrm{m} \text { fraction } \\
{[\%]}\end{array}$} & \multicolumn{2}{|c|}{$\begin{array}{c}\% \text { of }<63 \mu \mathrm{m} \text { fraction } \\
\text { in the sediments } \\
{[\%]}\end{array}$} \\
\hline & April & June & April & June & April & June \\
\hline$S W-5$ & 9.4 & 10.3 & 7.97 & 8.26 & 5.85 & 3.73 \\
\hline$S W-10$ & 10.9 & 19.1 & 8.89 & - & 13.56 & 2.10 \\
\hline$S W-20$ & 22.9 & 22.1 & 10.85 & 12.84 & 0.29 & 15.82 \\
\hline$S W-30$ & 15.1 & 9.9 & 13.61 & 8.07 & 9.27 & 26.09 \\
\hline$S W-40$ & 14.0 & 10.8 & - & 8.46 & 1.65 & 12.12 \\
\hline$S W-60$ & 5.9 & 5.0 & 7.76 & 6.25 & 54.97 & 65.48 \\
\hline
\end{tabular}


Table III. Tissue Cu concentration, glycogen content and the condition index in Macoma balthica in the Vistula River estuary.

\begin{tabular}{|c|c|c|c|c|c|c|c|c|}
\hline \multirow[t]{2}{*}{ Station } & \multicolumn{4}{|c|}{ Cu concentration $\left[\mu \mathrm{g} \cdot \mathrm{g}^{-1} \mathrm{DW}\right]$} & \multicolumn{2}{|c|}{ Glycogen [\%] } & \multicolumn{2}{|c|}{ Condition $\left[\mathrm{mg} \cdot \mathrm{cm}^{-3}\right]$} \\
\hline & \multicolumn{2}{|c|}{ April } & \multicolumn{2}{|c|}{ June } & \multirow{2}{*}{$\frac{\text { April }}{1.29}$} & \multirow{2}{*}{$\frac{\text { June }}{3.16}$} & \multirow{2}{*}{$\frac{\text { April }}{8.9}$} & \multirow{2}{*}{$\frac{\text { June }}{8.2}$} \\
\hline$S W-5$ & 34.53 & 43 & 18.96 & 66 & & & & \\
\hline$S W-10$ & 17.80 & 20 & 22.03 & 73 & 2.21 & 2.30 & 8.9 & 6.8 \\
\hline$S W-20$ & 33.98 & 34 & 30.63 & 10 & 0.86 & 5.57 & 6.2 & 6.6 \\
\hline$S W-30$ & 129.81 & 52 & 60.26 & 31 & 4.11 & 1.27 & 5.0 & 3.5 \\
\hline$S W-40$ & 55.97 & 67 & 135.38 & 10 & 1.39 & 2.33 & 7.0 & 7.8 \\
\hline$S W-60$ & 182.08 & 10 & 159.70 & 10 & 0.43 & 3.45 & 6.9 & - \\
\hline
\end{tabular}

Table IV. Significance of relationships between the $\mathrm{Cu}$ content in $<63 \mu \mathrm{m}$ sediment fraction or clams, and environmental and ecophysiological parameters (multiple and stepwise regression on average data) $(\%$-Org $=\%$-organic matter; Silt $=<63 \mu \mathrm{m}$ sediment fraction; Cond = condition; Glyc $=$ glycogen; ${ }^{* *} \mathrm{p}<0.01$, $* \mathrm{p}<0.05, \mathrm{~ns}=$ not significant).

\begin{tabular}{|c|c|c|c|c|c|}
\hline & Station & $\%$ Org & Silt & Cond & Glyc \\
\hline $\mathrm{Cu}$ content in silt & * & $* *$ & & & \\
\hline $\begin{array}{l}\text { Cu content in } \\
\text { M.balthica }\end{array}$ & * & $*$ & $* *$ & $\mathrm{~ns}$ & $\mathrm{~ns}$ \\
\hline
\end{tabular}

tions (table III). The $\mathrm{Cu}$ concentrations in the clams correlated with the silt fraction in the sediments $(r=0.74$, $\mathrm{n}=12, \mathrm{p}<0.01$; table IV; figure 3) and, to a lesser extent, to the organic fraction in silt (table IV). Glycogen content and the condition index of the clams did not reveal significant relationships with their $\mathrm{Cu}$ concentrations (table $\mathrm{I}$ ).

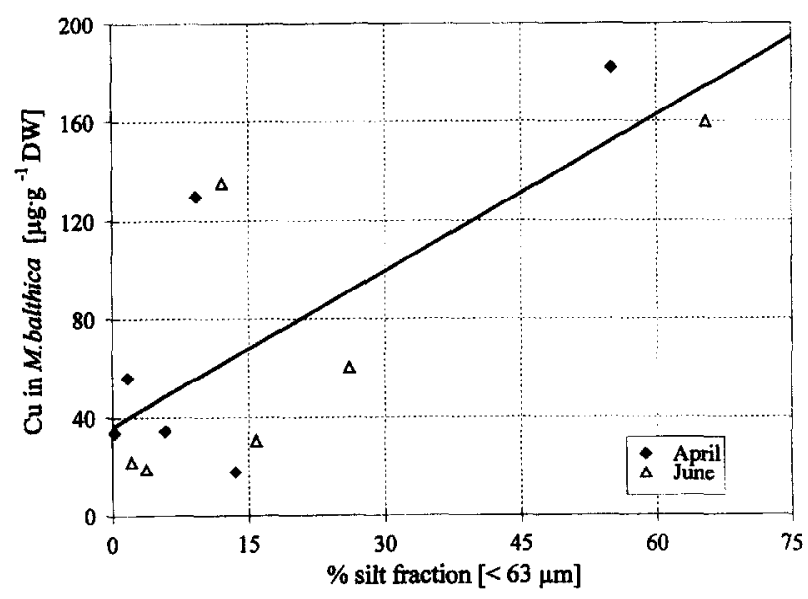

Figure 3. Correlation between the Cu concentration in Macoma balthica and percentage of silt fraction in surface sediments $(r=$ $0.74, \mathrm{n}=12, \mathrm{p}<0.01$ ).

\subsection{Experiments}

The particulate-associated $\mathrm{Cu}$ concentrations were higher than those in the dissolved phase (table $V$ ). So, Cu was bound to suspended particles and only a small part remained in dissolved form. The final average concentrations were higher than the nominal concentrations, which

Table V. Average $\mathrm{Cu}$ concentrations in water in each experiment treatment $(n=4)$.

\begin{tabular}{lccc}
\hline \multirow{2}{*}{$\begin{array}{l}\text { Treatment } \\
\text { (intended) }\end{array}$} & \multicolumn{3}{c}{ Measured Cu concentration $\left[\boldsymbol{\mu g} \cdot \mathbf{L}^{-\mathbf{1}}\right.$ ] } \\
\cline { 2 - 4 } & Dissolved & Particulate & Total \\
\hline Control & 2.4 & 14.3 & 16.7 \\
$37.5 \mu \mathrm{gCu} \cdot \mathrm{L}^{-1}$ & 20.4 & 21.0 & 41.4 \\
$75 \mu \mathrm{gCu} \cdot \mathrm{L}^{-1}$ & 38.8 & 66.9 & 105.7 \\
\hline
\end{tabular}

Table VI. Burrowing activity of Macoma balthica collected at two stations: GD and SO (St-tested at the start of the experiment, 0-control, 37.5 -exposure to $37.5 \mu \mathrm{gCu} \cdot \mathrm{L}^{-1}, 75$-exposure to $75 \mu \mathrm{gCu} \cdot \mathrm{L}^{-1}$ ).

\begin{tabular}{lcccccccc}
\hline Station & \multicolumn{3}{c}{ Percentage [\%] of the $\mathbf{2 0}$ animals burrowed after } \\
\cline { 2 - 9 } & \multicolumn{4}{c}{$\mathbf{6 0}$ minutes } & \multicolumn{5}{c}{$\mathbf{9 0}$ minutes } \\
\hline & St & 0 & 37.5 & 75 & St & 0 & 37.5 & 75 \\
GD & 55 & 35 & 20 & 0 & 70 & 35 & 25 & 0 \\
SO & 45 & 60 & 5 & 5 & 50 & 75 & 5 & 5 \\
\hline
\end{tabular}

Table VII. LT $_{50}$ (lethal time) for Macoma balthica from different stations at different $\mathrm{Cu}$ concentrations and percentage of mortality in control.

\begin{tabular}{lcccc}
\hline Station & \multicolumn{2}{c}{$\mathbf{L T}_{\mathbf{5 0}}$ [day] at } & & $\begin{array}{c}\text { \% mortality in } \\
\text { control * }\end{array}$ \\
\cline { 2 - 3 } \cline { 5 - 5 } & $\mathbf{3 7 . 5} \boldsymbol{\mu g C u} \cdot \mathrm{L}^{-\mathbf{1}}$ & $\mathbf{7 5} \boldsymbol{\mu g C u} \cdot \mathrm{L}^{-\mathbf{1}}$ & & (after 55 days) \\
\hline GD & 59 & 41 & 1 \\
SO & 51 & 33 & 11 \\
\hline
\end{tabular}

* - mortality was calculated on 100 individuals from four aquaria 
Table VIII. Biochemical composition and the condition index of Macoma balthica from two stations (GD, SO) before and after exposure to different $\mathrm{Cu}$ concentrations ( $\mathrm{n}=4$; FAA-free amino acids, St-start, 0 -control, 37.5 -exposure to $37.5 \mu \mathrm{gCu} \cdot \mathrm{L}^{-1} \cdot 75$-exposure to $75 \mu \mathrm{gCu} \cdot \mathrm{L}^{-1}$ ).

\begin{tabular}{|c|c|c|c|c|}
\hline $\begin{array}{l}\text { Station and } \\
\text { Cu concentration }\end{array}$ & $\begin{array}{c}\text { Total FAA } \\
{\left[\mu \mathrm{Mol} \cdot \mathrm{g}^{-1} \mathrm{DW}\right]}\end{array}$ & $\begin{array}{c}\text { Protein } \\
{[\%]}\end{array}$ & $\begin{array}{c}\text { Flycogen } \\
{[\%]}\end{array}$ & $\begin{array}{r}\text { Condition } \\
{\left[\mathrm{mg} \cdot \mathrm{cm}^{-3}\right]}\end{array}$ \\
\hline SO St & 194 & 51.60 & 10.93 & 9.09 \\
\hline SO 0 & 282 & 59.34 & 3.70 & 4.77 \\
\hline SO 37.5 & 250 & 67.83 & 2.79 & 4.81 \\
\hline SO 75 & 224 & 63.78 & 1.10 & 4.92 \\
\hline $\mathrm{GD} \quad \mathrm{St}$ & 196 & 50.64 & 13.59 & 10.93 \\
\hline GD 0 & 272 & 66.30 & 4.32 & 5.03 \\
\hline GD 37.5 & 299 & 61.08 & 3.32 & 5.50 \\
\hline GD 75 & 335 & 59.54 & 3.00 & 6.21 \\
\hline
\end{tabular}

Table IX. Free amino acid composition (\% of total) of Macoma balthica from two stations (GD, SO) before and after exposure to different Cu concentrations (St-start, 0 -control, 37.5 -exposure to $37.5 \mu \mathrm{gCu} \cdot \mathrm{L}^{-1}, 75$-exposure to $75 \mu \mathrm{gCu} \mathrm{L}^{-1}$ ).

\begin{tabular}{lrrrrrrrrrrr}
\hline $\begin{array}{l}\text { Station } \\
\text { Cu conc. }\end{array}$ & Asp & Glu & Ser & Gly & Tau & Arg & Ala & Val & Phe & Ile & Leu \\
\hline SO St & 3.8 & 10.9 & 3.5 & 23.8 & 0.4 & 13.3 & 23.3 & 0.4 & 16.2 & 0.4 & 0.4 \\
SO 0 & 6.7 & 5.7 & 3.0 & 42.7 & 0.4 & 6.5 & 20.1 & 0.2 & 9.6 & 1.9 & 1.2 \\
SO 37.5 & 7.7 & 6.3 & 2.8 & 31.4 & 0.5 & 9.0 & 21.6 & 0.2 & 16.5 & 0.0 & 2.2 \\
SO 75 & 2.0 & 5.3 & 3.0 & 26.3 & 0.0 & 8.7 & 38.6 & 0.5 & 12.7 & 0.9 & 2.1 \\
GD St & 1.5 & 9.9 & 5.0 & 21.1 & 0.0 & 14.8 & 26.0 & 0.0 & 15.8 & 0.0 & 3.9 \\
GD 0 & 7.1 & 7.4 & 2.9 & 37.9 & 0.0 & 8.2 & 24.6 & 0.0 & 8.8 & 0.0 & 0.8 \\
GD 37.5 & 4.4 & 6.4 & 2.3 & 32.5 & 0.3 & 9.7 & 27.8 & 0.2 & 8.8 & 0.0 & 2.6 \\
GD 75 & 1.1 & 6.9 & 2.8 & 20.5 & 0.0 & 7.0 & 43.5 & 1.7 & 11.8 & 0.9 & 1.9 \\
\hline
\end{tabular}

was due to contamination of the basic water (= control) and probably other unknown sources (table $V$ ). Organisms exposed to $\mathrm{Cu}$ concentrations of $75 \mu \mathrm{g} \mathrm{L}^{-1}$ kept their shells closed longer than the other tested groups ( 37.5 and $0 \mu \mathrm{g} \mathrm{L}^{-1}$ ). Significant differences in burrowing behaviour (table VI) and mortality (table VII) were observed between treatments (Wilcoxon matched pairs test, $p<0.07$ ). The percentage of animals burrowed after 60 or 90 min lowered with an increase in Cu concentrations and reached a minimum at $75 \mu \mathrm{g} \mathrm{L}^{-1}$ (table VI). The burrowing rate of the clams from the less polluted station (SO) was lower than that from the more contaminated station (GD) at $\mathrm{Cu}$ exposure 37.5 and $75 \mu \mathrm{g} \mathrm{L}^{-1}$. Differences between stations were also found for the mortality, with the highest mortality of animals from station SO (table VII). A decrease in glycogen content with $\mathrm{Cu}$ concentrations was observed. The changes in the condition index pale into insignificance beside the strong difference with the start situation (table VIII). For the other parameters (total free amino acid composition (FAA), protein) no consistent changes could be observed (tables VIII, IX).
Yet, for both stations at $\mathrm{Cu}$ exposure $75 \mu \mathrm{g} \mathrm{L}^{-1}$ an increase of $\mathrm{Ala}$ and a decrease of Gly were found (table IX).

\section{DISCUSSION}

Our data on the $\mathrm{Cu}$ content in sediments show a steady gradient with highest values at $20 \mathrm{~m}$ water depth and a strong decrease landwards (to $5 \mathrm{~m}$ ) and seawards (to $60 \mathrm{~m}$ ). Such a spatial distribution reflects an effect of fresh riverine water outflow, and mixing processes of fresh and brackish water masses, on dilution and precipitation rates of metals in the estuary, with a turbidity maximum at the mixing zone [9]. During estuarine mixing, the adsorption of dissolved $\mathrm{Cu}$ by flocculated oxyhydroxids of $\mathrm{Mn}$ and $\mathrm{Fe}$ and associated humic substances leads to increased coprecipitation and results in high $\mathrm{Cu}$ and organic matter content in the sediments (station SW20). The positive relationship between organic matter and $\mathrm{Cu}$ in the silt fraction displays this coprecipitation 
and affinity of $\mathrm{Cu}$ for organic substances, as is commonly observed $[9,24]$. As a result, at deeper stations $\mathrm{Cu}$ levels in the silt fraction drop with depth. Yet, the silt fraction may still increase with depth (the highest silt fractions are found at $60 \mathrm{~m}$ depth, table II). Consequently the total $\mathrm{Cu}$ content (which can be calculated as the product of the silt fraction and the $\mathrm{Cu}$ content of the silt) in the sediments may also be high at the deeper stations. This explains why the highest $\mathrm{Cu}$ values in the clams were found at the deeper stations, as also indicated by the positive relation between the $\mathrm{Cu}$ concentration in clams and the silt fraction. Yet, $\mathrm{Cu}$ uptake from the water can not be excluded as a source. Part of the $\mathrm{Cu}$ in the clam might be derived from the sediment, whereas another part may be ingested with food from the suspension [1], because clams are capable of both suspension and deposit feeding [4]. Data on dissolved $\mathrm{Cu}$ in the water from the gradient studied by us available for 1997 revealed low concentrations however (Sokolowski, unpubl. data).

In order to assess the influence of $\mathrm{Cu}$ accumulation on the physiology of $M$. balthica, the glycogen content and the condition index were analyzed as indicators of stress. The application of these parameters for the detection of environmental stress in $M$. balthica has been suggested by Hummel et al. [14]. It is known that stressful conditions brought about by environmental factors can result in a change of the metabolic activity in clams and may imply an increased energy charge [25]. High-energy reserve constituents start to be metabolized in order to cover the enhanced energy demand. The increase of catabolic reactions in the organism leads to a decrease of the physiological condition involving e.g. a decrease in glycogen content and the condition index [14]. In the present study, the glycogen content indeed decreased during the experiments. However no relationship was found between $\mathrm{Cu}$ concentrations and the condition index or glycogen level in the field. The absence of such a relationship might be enhanced by the reproduction under normal conditions. Spawning of gametes, which implies a loss of body weight, starts usually in May-June. The reproductive cycle in $M$. balthica from different depths does not occur synchronously [31]. Thus, the absence of a relationship between the $\mathrm{Cu}$ content and glycogen or the condition index in spring may result also from a different reproduction-related physiological state of the clams. Therefore, in the Baltic, glycogen and the condition index are not proper indicators of stress in $M$. balthica during the spawning season.
Similarly, the free amino acids (FAA) proved not to be a proper indicator of stress in Baltic populations. This is in contrast to FAA in clams from Atlantic coasts and estuaries [15]. Remarkable was the low level of the total FAA in the clams from the Baltic (less than $50 \%$ of that in Atlantic specimens), and the almost total absence of taurine, whereas it is present in substantial amounts, up to $20 \%$, in Atlantic clams [15]. This may be due to the low salinity in the Baltic, since FAA are used in osmoregulation $[5,19]$ or because of genetic differences between Atlantic and Baltic populations [30]. So, for Baltic specimens the taurine/glycine ratio has a low stress indicating value.

The "burrowing activity" tests showed that the clams burrowed slower at higher $\mathrm{Cu}$ concentrations. A similar reaction was found for Atlantic specimens when exposed to increasing concentrations of $\mathrm{Cu}[14,22]$. An explanation for Cu-driven differences in burrowing lies in differences in the clam's behaviour. $\mathrm{Cu}$-stressed organisms kept their shells closed longer than the control and thus were not able to actively burrow. Such an interpretation is supported by the changes of Ala and Gly, which represent a rapid metabolic turnover [5]. At a $\mathrm{Cu}$ exposure of $75 \mu \mathrm{g} \mathrm{L}^{-1}$ clams revealed an increased concentration of Ala which is an end product in the glycolytic metabolism during anaerobic respiration, and thus may reflect the prolonged duration of shell closure. On the other hand, a drop of Gly was observed. Gly is involved in metabolism of a variety of gluconeogenic compounds, so it may indicate a high metabolic level.

Comparison of the results on the "burrowing activity" and mortality between populations from station GD and SO provided information on differences in the sensitivity to $\mathrm{Cu}$ of organisms collected from two arcas differing in the degree of pollution. The bivalves from the relatively unpolluted station (SO) showed higher mortality and lower burrowing activity and thus more "stressed" reactions. However, more active behavior of these organisms was observed in controls. It may indicate that the clams from the unpolluted area are not adapted to changes in their habitat and are more sensitive to additional stress.

\section{CONCLUSION}

We can conclude that burrowing activity and mortality are the best indicators of $\mathrm{Cu}$-induced stress in $M$. bal- 
thica. The condition index, glycogen content, and free amino acid composition were not reliable stress indicators. The use and sensitivity of these last named indicators might have been obscured by changes in the physiology of the organisms related to reproduction.

\section{Acknowledgements}

The authors wish to thank Elizabeth T. Merrick from St. Andrews College, North Carolina for editing the English of this manuscript. This research was supported by E.C. Project ERB-CIPA-CT-92-2275 to M.W.

\section{REFERENCES}

[1] Absil M.C.P., Kroon J.J., Wolterbeek H.T., Availability of $\mathrm{Cu}$ from phytoplankton and water for the bivalve Macoma balthica. II, Uptake and elimination from ${ }^{64} \mathrm{Cu}$-labeled diatoms and water, Mar. Biol. 118 (1994) 129-135.

[2] Anonymous, Report on sanitary state of Gdansk voivodeship in 1994, (in Polish), editcd by Pañstwowa Inspekcja Ochrony Srodowiska, Wojewódzki Inspektorat Ochrony Srodowiska w Gdansku (1995) 67-76.

[3] Beukema J.J., de Bruin W., Seasonal changes in dry weight and chemical composition of the soft part of the tellinid bivalve Macoma balthica in the Dutch Wadden Sea, Neth. J. Sea Res. 11 (1977) 42-55.

[4] Beukema J.J., Cadée G.C., Growth rates of the bivalve Macoma balthica in the Wadden Sea during a period of eutrophication: relationships with concentrations of pelagic diatoms and flagellates, Mar. Ecol. Prog. Ser. 68 (1991) 249 256.

[5] Bishop S.H., Ellis L.L., Burcham J.M., Amino acid metabolism in molluses, in: The Mollusca, Vol. 1, (Ed.) Academic Press Inc., New York, 1983, 243-293.

[6] Bryan G.W., Langston W.J., Bioavailability, accumulation and effects of heavy metals in sediments with special references to United Kingdom estuaries: a review, Environ. Pollut. 76 (1992) 89-131.

[7] Cain D.J., Luoma S.N., Influence of seasonal growth, age and environmental exposure on $\mathrm{Cu}$ and $\mathrm{Ag}$ in a bivalve indicator, Macoma balthica, in San Francisco Bay, Mar. Ecol. Prog. Ser. 60 (1990) 45-55

[8] Dubois M., Gilles K.A., Hamilton J.K., Bebecs P.A., Smith F., Calorimetric method for determination of sugars and related substances, Anallit. Chem. 28 (1956) 350-356.

[9] Flemming C.A., Trevors J.T., Cu toxicity and chemistry in the environment: A review, Water Air Soil Poll. 44 (1989) 143158.

[10]Gerringa L.J.A., Poortvliet T.C.W., Hummel H., Comparison of chemical speciation of copper in the Oosterschelde and Westerschelde cstuaries, the Netherlands, Est. Coast. Shelf Sci. 42 (1996) 629-643

[11] Giese A.C., Some methods for study of the biochemical constitution of marine invertebrates, Oceanogr., Mar. Biol. Ann. Rev. 5 (1967) 159-186.

[12] Hummel H., Patarnello T., Genetic effects of pollutants on marine and estuarine invertebrates, in: Genetics and evolution of aquatic organisms, Beaumont A.R., Chapman \& Hall (Eds.), 1994, 425-433.

[13] Hummel H., Bogaards R.H., Amiard-Triquet C., Bachelet G., Desprez M., Marchand J., Rybarczyk H., Sylvand B., de Wit Y., de Wolf $L$,, Uniform variation in genetic traits of a marine bivalve related to starvation, pollution and geographic clines, J. Exp. Mar. Biol. Ecol. 191 (1995) 133-150.

[14] Hummel H., Amiard-Triquet C., Bachelet G., Desprez M., Marchand J., Sylvand B., Amiard J.C., Rybarczyk H., Bogaards R.H., Sinke J, de Wit Y., de Wolf L., Sensitivity to stress of the estuarine bivalve Macoma balthica from areas between The Netherlands and its southern limits (Gironde), Neth. J. Sea Res. 35 (1996a) 315-321.

[15] Hummel H., Amiard-Triquet C., Bachelet G., Desprez M., Marchand J., Sylvand B., Amiard J.C., Rybarczyk H., Bogaards R.H., Sinke J., de Wit Y., de Wolf L., Free amino acids as a biochemical indicator of stress in the estuarine hivalve Macoma balthica, Sci. Tntal. Fnviron. 188 (1996b) 233-241.

[16] Janas U., Szaniawska A., The influence of hydrogen sulphide on macrofaunal biodiversity in the Gulf of Gdansk, Oceanologia 38 (1) (1996) 127-141.

[17] Keppler D., Decker K., Glycogen, Determination with Amyloglucosidase, in: Bergmeger H.U. (Ed.), Methods of enzymatic analysis. Vol. 3, Academic Press, New York, 1974, $1127-$ 1131.

[18] Lagadic L., Caquet F., Ramade The role of biomarkers in environmental assessment 5 , Invertebrate populations and communities, Ecotoxicol. 3 (1994) 193-208.

[19] Livingstone D.R., General biochenical indices of sublethal stress, Mar. Poll. Bull. 13 (1982) 261-263

[20] Luoma S.N., Bryan G.W., A statistical assessment of the forms of trace metals in oxidised estuarine sediments employing chemical extractants, Sci. Total Environ. 17 (1981) 165-196

[21] Mart L., Ermittlung und Vergleich des Pegels Toxischer Spurenmetalle in Nordatlantischen und Mediterranen Küstengewässern. PhD Thesis, Tcchnische Hochschule, Aachen, Deutschland, 1979, $354 \mathrm{p}$.

[22] McMahon R.J.. Wilson P., Seasonal respiratory responses to temperature and hypoxia in relation to burrowing depth in three intertidal bivalves, J. Therm. Biol. 6 (1981) 267-277

[23] Meehan B.W., Carlton J.T., Wenne R., Genetic affinities of the bivalve Macoma balthica from the Pacific coast of North 
America: evidence for recent introduction and historical distribution, Mar. Biol. 102 (1989) 235-241.

[24] Millward G.E., Processes affecting trace element speciation in estuaries, A review, Analyst, 120 (1995) 609-614.

[25] Neuhoff H.G., Synergistic physiological effects of low $\mathrm{Cu}$ and various oxygen concentrations on Macoma balthica, Mar. Biol. 77 (1983) 39-48.

[26] Nieuwenhuize J., Poley-Vos C.H., van den Akker A.H, van Delft W., Comparison of microwave and convential extraction techniques for the determination of metals in soil, sediment and sludge samples by atomic spectrometry, Analyst, 116 (1991) 347-351.

[27] Sokal R.R., Rohlf F.J., Biometry, (Ed.) Freeman and Co., New York, 1995, 1-887.

[28] Szefer P., Mass-balance of metals and identification of their sources in both river and fallout fluxes near Gdansk Bay, Baltic Sea, Sci. Total Environ. 95 (1990) 131-139.
[29] Szefer P., Glasby G.P., Pempkowiak J., Kaliszan R., Extraction studies of heavy-metal pollutants in surficial sediments from the southern Baltic Sea off Poland, Chem. Geol. 120 (1995) 111-126.

[30] Vainola R., Varvio S.L., Biosystematics of Macoma balthica in northwestern Europe, Olsen \& Olsen, Fredenborg (Eds.), Proc. 23rd Europ. Mar. Biol. Symp, (1989) 309-317.

[31] Wenne R., Zróznicowanie przestrzenne i ewolucja wybranych gatunków malzy morskich. (in Polish), Wydawnictwo Uniwersytetu Gdañskiego, 1993, 160 p.

[32] Wolowicz M., Impact de l'activité humaine sur les variations inter-annuelles de la malacofaune benthique en baie de Puck (S. Baltique), Haliotis 23 (1994) 43-50.

[33] Zwarts L., Wanink J., Siphon size and burying depth in deposit- and suspension-feeding benthic bivalves, Mar. Biol. 100 (1989) 227-240.

[34] Zmudzinski L., Osowiecki A., Long-term changes in the bottom macrofauna of the Puck Lagoon, Acta Ichtiol. Et Pisc. 21 (1991) 259-266. 